\title{
Whole Blood Collection Tube
}

National Cancer Institute

\section{Source}

National Cancer Institute. Whole Blood Collection Tube. NCI Thesaurus. Code C113392.

A blood collection tube used for the collection of whole blood. 